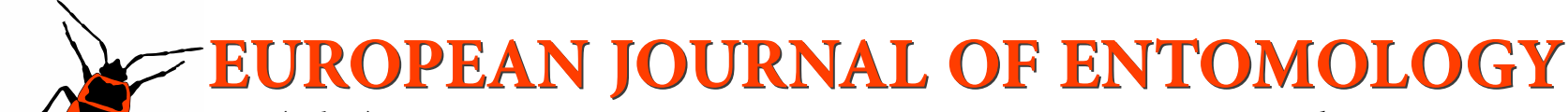 \\ ISSN (online): 1802-8829 \\ http://www.eje.cz \\ Eur. J. Entomol. 115: 296-302, 2018 \\ doi: 10.14411/eje.2018.028 \\ ORIGINAL ARTICLE
}

\section{Fine structure of the external sheaths of the ovipositor of Aphidius ervi (Hymenoptera: Braconidae)}

\author{
SARA RUSCHIONI ${ }^{1}$, PAOla RIOLO ${ }^{1, *}$, Roberto ROMANI ${ }^{2}$, Donatella BATTAGLIA ${ }^{3}$ and NunzIO ISIDORO ${ }^{1}$ \\ ${ }^{1}$ Dipartimento di Scienze Agrarie, Alimentari ed Ambientali, Università Politecnica delle Marche, via Brecce Bianche, \\ 60131 Ancona, Italy; e-mails: s.ruschioni@univpm.it, p.riolo@univpm.it, n.isidoro@univpm.it \\ ${ }^{2}$ Dipartimento Di Scienze Agrarie, Alimentari e Ambientali, Università degli Studi di Perugia, Borgo XX Giugno 74, \\ 06121 Perugia, Italy; e-mail: roberto.romani@unipg.it \\ ${ }^{3}$ Dipartimento di Scienze, Università degli Studi della Basilicata, Viale dell'Ateneo Lucano 1, 85100 Potenza, Italy; \\ e-mail: donatella.battaglia@unibas.it
}

Key words. Hymenoptera, Braconidae, Aphidius ervi, ultrastructure, ovipositor valve, parasitoid, gland, marking pheromone

\begin{abstract}
The function and structure of the ovipositor in Hymenoptera have been studied intensively, although there is a lack of information on the external sheaths. We provide here a contribution on the structure of the external sheaths of the ovipositor of the parasitic wasp Aphidius ervi, in particular the secretory structure is described for the first time. These glands are made up of a large epithelial structure that consists a single layer of large secretory cells that occupy most of the lumen of the valve and belong to gland cell class 1 . Based on the different features of the glands, a lubricating and/or host marking function is hypothesized and discussed.
\end{abstract}

\section{INTRODUCTION}

The insect ovipositor has developed from the primary segmental appendages of the eighth and ninth abdominal segments (Scudder, 1961a, 1964, 1971). In Hymenoptera, the ovipositor is unique among the endopterygotes in having a well-developed apparatus in which basal articulations are present (Kristensen, 1991; Vilhelmsen, 2000). The function of the ovipositor in parasitic Hymenoptera is to lay eggs on or inside different species of suitable hosts living in very different habitats (Vilhelmsen, 2000; Vilhelmsen et al., 2001). It has also a key role both in informing the parasitoid of the condition of the host and in marking the host with oviposition-deterring substances (Vinson, 1998; Ruschioni et al., 2015a).

The anatomy and mechanics of the ovipositor are presumably adapted to the diversity of hosts and host-associated substrates into or onto which parasitoids deposit their eggs and this might have contributed to the high diversity of species in the Hymenoptera (Field \& Austin, 1994; Quicke et al., 1999). The basic functional elements of the ovipositor are, however, very similar (Snodgrass, 1935; Scudder 1961b, 1971; Smith, 1969; Copland \& King, 1972; Richards, 1977; Austin \& Browning, 1981). Ovipositors have three pairs of valvulae and two pairs of valvifers. The lat- ter are situated basally and the second pair, with the ninth tergite, accommodates the main muscles that extend and retract the ovipositor proper (Oeser, 1961). The valvulae do not have a musculature (Quicke et al., 1999; Vilhelmsen, 2000). The first and second valvulae constitute the ovipositor proper and are joined together and connected in a way that they can be moved (Vilhelmsen, 2003). The third valvulae form the external sheath of the ovipositor (Vilhelmsen, 2003).

While the ovipositor proper of many parasitoid wasps has been studied in some detail (Quicke et al., 1995; Brown \& Anderson, 1998; van Lenteren et al., 1998), the external sheaths have not received the same attention, and little data are available on their structural features. The ovipositor is generally very thin and therefore is easily damaged if it protrudes from the posterior end of the metasoma. It would thus appear that the external sheaths have evolved to protect the ovipositor when it is not in use (Scudder, 1971; Austin, 1983; Vilhelmsen, 2003). Although in the Aculeata the protective function of the third valvulae is taken over by the abdomen, the valvulae might still have a role in host detection and selection. Indeed, there are some sensilla on the valvulae that might fulfil such a role (Quicke et al., 1999; Larocca et al., 2007). Another theory proposes that

\footnotetext{
* Corresponding author; e-mail: p.riolo@univpm.it
} 
the function of the external sheaths is to clean the ovipositor (Vilhelmsen, 2003).

In the Braconidae, the ovipositor generally protrudes from the metasoma, is strongly sclerotized and lodged within the external sheath (Snodgrass, 1933; Askew, 1971; Scudder, 1971). Larocca et al. (2007) report the ultrastructural details of the ovipositor of Aphidius ervi Haliday, but do not present any data on the external sheaths.

Here we describe the external sheaths of $A$. ervi and report for the first time an associated secretory structure. The morphological features and the possible functional significance of this gland are discussed.

\section{MATERIAL AND METHODS}

\section{Insects}

The A. ervi used in the present study was reared in the laboratory on pea aphid (Acyrthosiphon pisum Harris) maintained on potted broad bean (Vicia faba Linnaeus) plants. The aphid and parasitoid cultures were maintained in two separate environmental chambers at $20 \pm 1{ }^{\circ} \mathrm{C}$ and $75 \% \pm 5 \%$ relative humidity, under $18 \mathrm{~L}: 6 \mathrm{D}$ photoperiod.

\section{Scanning electron microscopy}

Ten $A$. ervi females were anaesthetized by exposure to cold temperature $\left(-18^{\circ} \mathrm{C}\right)$ for $60 \mathrm{~s}$ and then dipped in $60 \%$ alcohol. The ovipositor was removed from the abdomen and dehydrated using a graded series of ethanol concentrations, from $60 \%$ to $99 \%, 15$ min in each; the last step was repeated twice. After dehydration, the $99 \%$ ethanol was replaced with pure hexamethyldisilazane (Sigma), and the specimens were allowed to dry under a hood, under room conditions. Ten ovipositors were mounted on aluminium stubs and gold-sputtered (SCD 040 unit; Balzers Union, Vaduz, Liechtenstein). Observations were carried out using a scanning electron microscope FE-SEM SUPRA 40 (Carl Zeiss NTS GmbH, Oberkochen, Germany) at $10 \mathrm{kV}$ and with a window diameter of $9 \mathrm{~mm}$ to $10 \mathrm{~mm}$, and analyzed using SMART-SEM software (V05.04: 08.v.2009; Zeiss, Oberkochen, Germany).

\section{Transmission electron microscopy}

Ten females of $A$. ervi were anaesthetized by exposure to a temperature of $-18^{\circ} \mathrm{C}$ for $60 \mathrm{~s}$, and then immediately immersed in a solution of $1 \%$ glutaraldehyde and $2.5 \%$ paraformaldehyde in $0.1 \mathrm{M}$ cacodylate buffer and 5\% sucrose, $\mathrm{pH} 7.2-7.3$. The entire ovipositor was detached from its base, transversally cut in the middle to facilitate the penetration of the fixative, and left at $4^{\circ} \mathrm{C}$ for $2 \mathrm{~h}$. The specimens were kept at $4^{\circ} \mathrm{C}$ overnight in $0.1 \mathrm{M}$ cacodylate buffer and 5\% sucrose, $\mathrm{pH} 7.2-7.3$, then post-fixed in $1 \% \mathrm{OsO}_{4}$ for $1 \mathrm{~h}$ at $4{ }^{\circ} \mathrm{C}$ and rinsed in the same buffer. Dehydration in a graded series of ethanol from $60 \%$ to $99 \%$ was followed by embedding in Epon-Araldite, with propylene oxide as the bridging solvent. Thin sections were cut using a diamond knife (Drukker, Cuijk, The Netherlands) on an ultramicrotome (Nova; LKB, Bromma, Sweden) and then mounted on formvarcoated 50 -mesh grids. The sections on the grids were stained with uranyl acetate (20 min, room temperature) and lead citrate ( $5 \mathrm{~min}$, room temperature). Finally, the sections were examined under a transmission electron microscope (EM 208; Philips, FEI Company, Eindhoven, The Netherlands). Digital pictures ( 8 bit greyscale
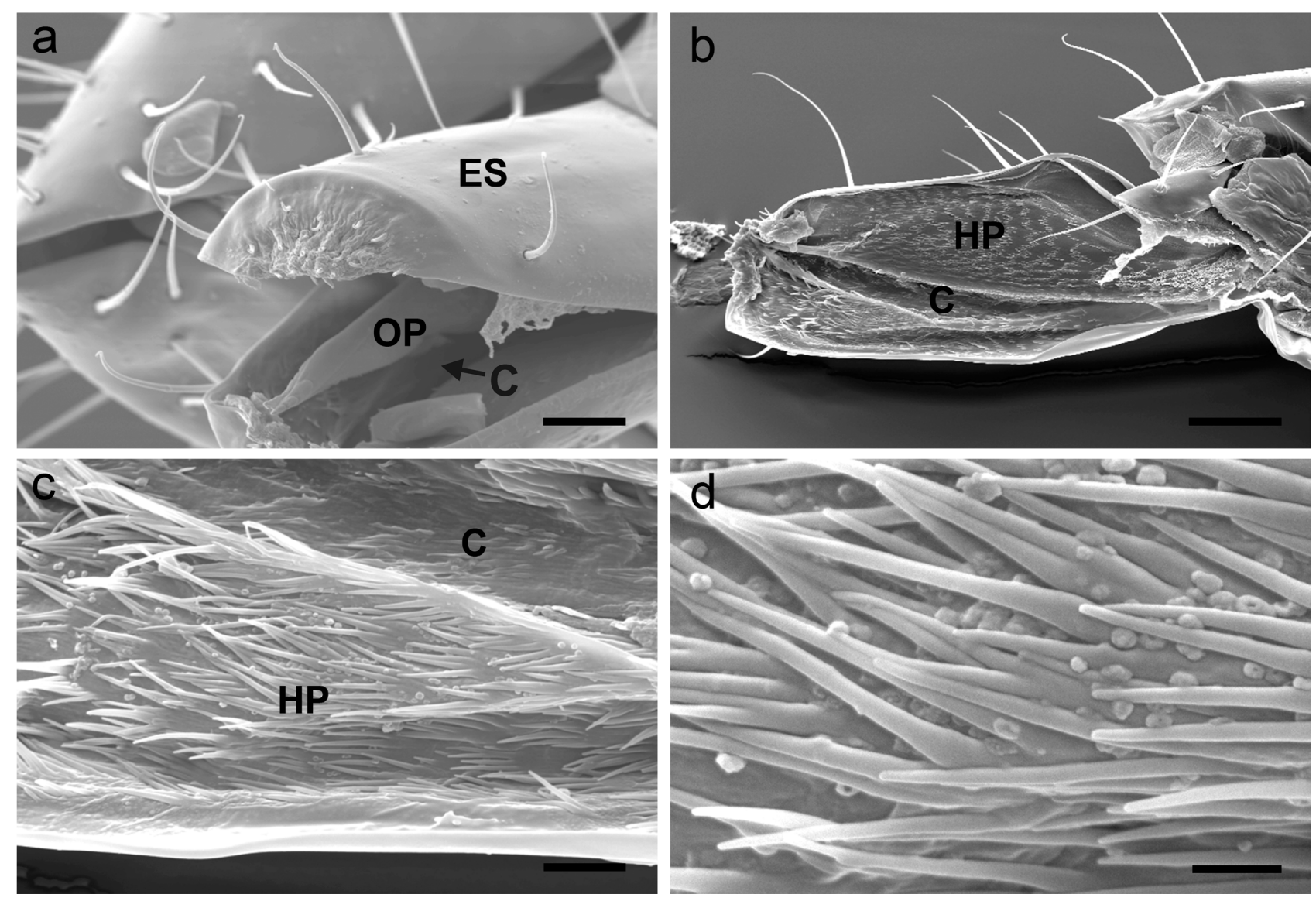

Fig. 1. Scanning electron micrographs. a - Aphidius ervi ovipositor (OP) enclosed by the external sheaths (ES). The ovipositor canal is visible (C). $b$ - internal view of the external sheath, showing the ovipositor canal $(C)$ and the hair-like projections (HP). $c-$ details of the structure of cuticle characterized by hair-like projections. $d$ - hair-like projections. Scale bars: a, b: $25 \mu \mathrm{m}$; c: $2.5 \mu \mathrm{m}$; d: $1.5 \mu \mathrm{m}$. 

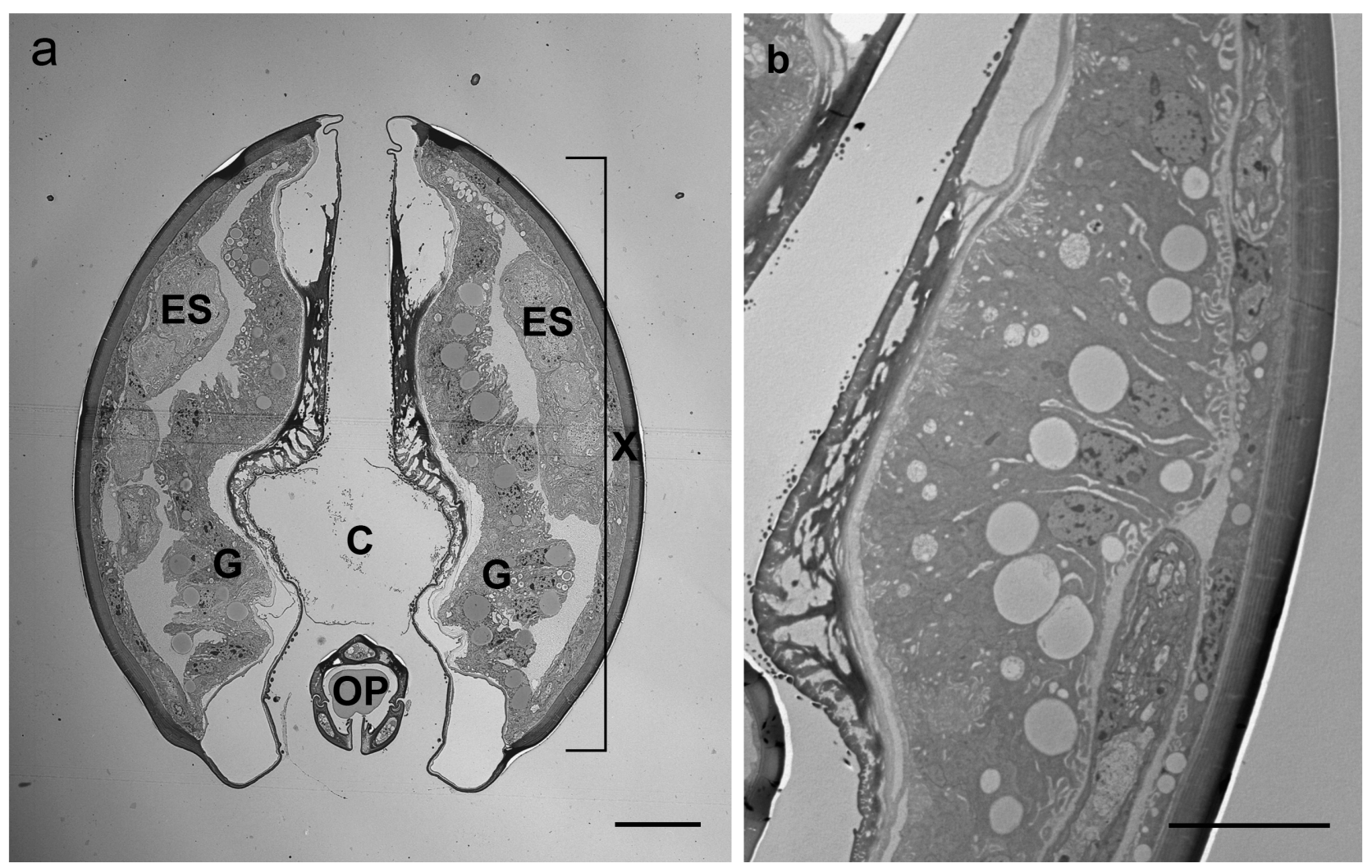

Fig. 2. Transmission electron micrographs of cross-sections of: a - external sheaths (ES) delimiting the canal (C) where the ovipositor $(\mathrm{OP})$ is located, showing the gland $(\mathrm{G})$ and its extension $(x=150 \mu \mathrm{m})$. In this preparation the ovipositor is located just below the ovipositor canal. $b$ - detail of the glandular epithelium. Scale bars: a: $10 \mu \mathrm{m}$; b: $20 \mu \mathrm{m}$.

TIFF files) were obtained using a high resolution digital camera (MegaViewIII; SIS and Olympus, Tokyo, Japan) connected to the transmission electron microscope.

\section{RESULTS}

The third valvulae (forming the external sheath) of $A$. ervi are seven times broader than the ovipositor proper, and have a smooth cuticle on their external surface (Fig. 1a). Scanning electron microscopy of the inner surface shows numerous hair-like projections, interspersed with small sub-spherical particles, with their apex orientated towards the distal end of the valvula (Fig. 1b-d). A longitudinal internal canal is delimited by the medial surfaces of both valvulae (Fig. 1b) and is where the ovipositor is held at rest. Distally, the external sheaths are truncated and have a wrinkled cuticle (Fig. 1a). The cross-section of the external sheaths shows a half-elliptical shape (Fig. 2a); at rest the internal surfaces delimit two cylindrical hollow spaces, the upper of which is the ovipositor canal (Fig. 2a). The cuticle lining the external surface of the third valvula is smoother and thicker when compared with the inner surface, on which there are many typical multiple cuticular invaginations (Fig. 2a, b). Lining the lumen of the external sheath is an extensive epithelium (Fig. 2a, b) the cells of which are in close contact with the internal cuticular wall. The epithelium is made up of a single layer of large secretory cells that occupy most of the valvula lumen (Fig. $2 \mathrm{a}, \mathrm{b})$. At the bases of the cells there are deep infoldings and large electron-lucid vesicles (Figs 2b, 3b), which are also present in the cytoplasm of the cells along with stacks of rough endoplasmic reticulum (Fig. 3b) and numerous slender mitochondria. In the apical region of the cells the microvilli are connected with the innermost cuticular layer, which is electron dense and has many filaments. The cuticle is thicker in the medial part of the valvula, and has a complicated pattern of digitiform projections and infoldings (Fig. 3a, c). In cross-section, this part shows a spongelike structure, which is perforated by numerous tiny pores (Fig. 3a,d). The release sites of these glands are positioned very close to the longitudinal internal upper canal.

\section{DISCUSSION}

This study shows that in $A$. ervi, the interior of each external sheath is characterized by the presence of numerous hair-like projections (microtrichia) that are interspersed with small sub-spherical particles, with their apex orientated towards the distal end of the valve. In other Braconidae, Vilhelmsen (2003) reports microtrichia of different densities and shapes on the inner wall of the external sheaths. According to Vilhelmsen (2003), this structure appears to clean the ovipositor proper between ovipositions. This function is fundamental, since it is important for female parasitoids to keep the ovipositor sensilla clean in order to maintain their functionality.

The present study reports for the first time, in a parasitic wasp, the presence of a gland in the external sheaths. Usually the size of the third valvulae is just sufficient to enclose the ovipositor proper, in $A$. ervi the area enclosed 

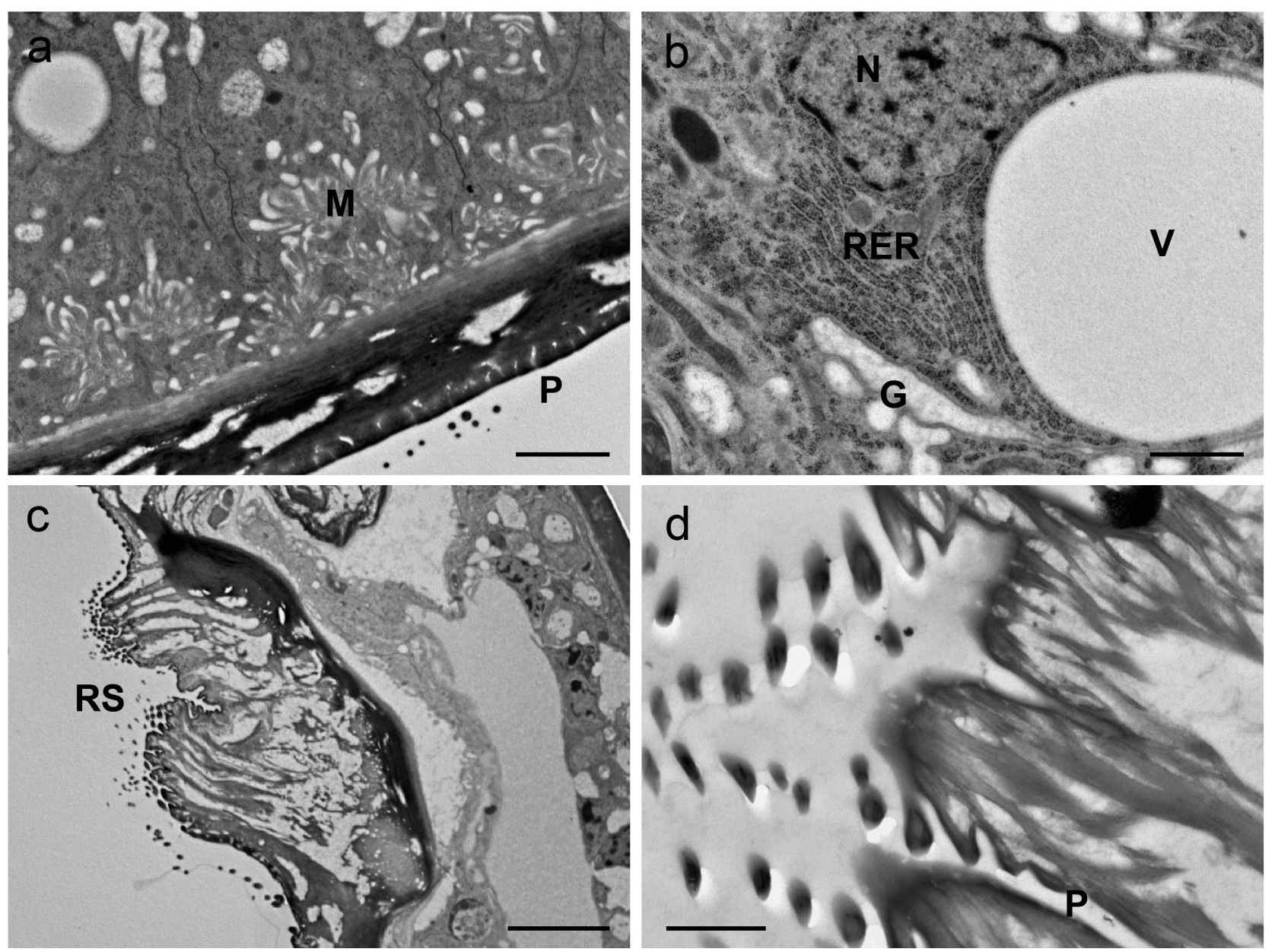

Fig. 3. Transmission electron micrographs of cross-sections of the external sheaths at the gland level. a - detail of the apical part of the secretory cells, showing abundant microvilli (M) just below the cuticle. b - close-up of a secretory cell, showing rough endoplasmic reticulum (RER), nucleus (N), Golgi apparatus (GO) and large electron-lucid secretory vesicles (V). c - cross-section at the level of the release site (RS). $d$ - detail of the release site, showing the canal pores (P). Scale bars: $a: 2 \mu \mathrm{m} ; b, d: 1 \mu \mathrm{m} ; \mathrm{c}$ : $5 \mu \mathrm{m}$.

is much greater than that needed to enclose the ovipositor proper, most likely to make room for the glands. The glandular epithelium is made up of a single layer of secretory cells that are directly in contact with the cuticle. According to the classification of insect epidermal glands proposed by Quennedey (1998), the secretory cells associated with the external sheaths in $A$. ervi belong to class 1 , as they are in direct contact with the external cuticle and lack specialized transporting cells or cuticular ducts.

A similar structure is described by Tagawa (1977) on the inner surface of the second valvifer of the braconid Apanteles glomeratus L., and is known to secrete a pheromone (Obara \& Kitano, 1974; Tagawa, 1977). Several studies report that Hymenoptera, including parasitic wasps, secrete female sex pheromones (Whiting, 1932; Boush \& Baerwald, 1967; Cole, 1970; Vinson, 1972; Cormier et al., 1998). However, only in a few cases is the location of these pheromone-producing glands known. In Campoletis sonorensis (Cameron) (Ichneumonidae), the sex pheromone appears to be produced over the whole body (Vinson, 1972), in Cardiochiles nigriceps Viereck (Braconidae), Dufour's gland is the source of the sex pheromone (Vinson, 1978), while in Apanteles melanoscelus Ratzeburg (Braconidae), the gland is located on the ninth tergite. Tagawa (1983) investigated seven other braconid species, and reports the female sex-pheromone-producing glands being located on the ninth tergite and/or second valvifer.

In the present study, we observed that in $A$. ervi the release sites of the gland located in the external sheaths are on the inner surface of the valvulae, which partially hides them. These release sites are positioned very close to the longitudinal internal canal, where the ovipositor is held when at rest. This position does not appear suitable for the release of a volatile sex pheromone and is not in accordance with that usually described in the literature for sex-pheromone-producing glands (Percy \& Weatherst, 1971; Levinson \& Levinson, 1995; Raina et al., 2000; Billen, 2009; Riolo et al., 2014), although this needs to be confirmed.

Host marking involves the release of chemical and/or physical signals (marks) on and/or inside a host, and is common among parasitoid insects (Hofsvang, 1990; van Alphen \& Visser, 1990). The evidence that insects hostmark with pheromones and that they are perceived by contact chemoreceptive sensilla is well documented (Rabb \& Bradley, 1970; Holler et al., 1991; Wang \& Huang, 1991; 
Ruschioni et al., 2015b). Parasitized hosts that remain in a habitat can be re-encountered, and host-marking pheromones that indicate that the host has already been parasitized regulate the host choice for oviposition of females (Gardner et al., 1984). A female that perceives the hostmarking pheromone can reject that host and invest time in searching for other hosts. Host-marking pheromones also act as epideictic messages that trigger the dispersal of parasitoids from sites that are already occupied when the population density is near optimal (Vinson, 1985; Roitberg \& Prokopy, 1987; Roitberg \& Mangel, 1988). Parasitoid females may use internal or external marks, or both, to indicate which hosts are already parasitized (Salt, 1937; van Lenteren, 1976, 1981; Hofsvang, 1990). In most cases, the sources of marking pheromones are associated with the female reproductive tract (Vinson, 1985; Holler et al., 1993; Marris et al., 1996; Quicke, 1997; Rosi et al., 2001). In addition, in some cases the secretion of accessory gland acts both as a lubricant, to facilitate the passage of eggs (Hosken \& Ward, 1999; Sturm \& Pohlhammer, 2000; Dallai et al., 2008) and a host-marking pheromone (Quicke, 1997; Rosi et al., 2001). Our observations show two canals enclosed by the third valvulae, only the upper of which is occupied by the ovipositor proper. The glandular epithelium and the release site of the glands are located on the inner surface of the upper canal, which may serve as a reservoir for the secretions from these glands. One function of the substances secreted by these glands can be an external host-marking pheromone; they could be smeared onto the outer surface of the ovipositor proper or applied directly during egg laying.

The valves of the ovipositor proper are held together by a complicated interlocking mechanism that allows them to slide back and forth on one another (Snodgrass, 1933; Smith 1968; King \& Copland, 1969; Smith, 1970; Askew, 1971; Quicke et al., 1995; van Lenteren, 1998). Austin (1983) describes the mechanics of the ovipositor system in detail, which are characterized by the extension and retraction of the ovipositor dependent on the rotation of the valvifers; here, the external sheaths should provide support and guidance for the ovipositor proper. This movement provides the functional basis for piercing the host and for moving the eggs along the shaft of the ovipositor (Austin \& Browning, 1981). The substances produced by the glands in the external sheaths could also serve as a lubricant during the extension and retraction of the ovipositor proper, especially as oviposition by $A$. ervi is very quick $(<0.5 \mathrm{~s})$ (Volkl \& Mackauer, 2000). However, further studies are needed to determine the chemical nature of the substances secreted by the gland and their function(s).

ACKNOWLEDGEMENTS. The authors thank the reviewers and article editor for their helpful suggestions that improved the manuscript.

\section{REFERENCES}

Askew R.R. 1971: Parasitic Insects. Heinemann Educational Books, London, 366 pp.
Austin A.D. 1983: Morphology and mechanics of the ovipositor system of Ceratobaeus Ashmead (Hymenoptera: Scelionidae) and related genera. - Int. J. Insect Morphol. Embryol. 12: 139-155.

Austin A.D. \& Browning T.O. 1981: A mechanism for movement of eggs along insect ovipositors. - Int. J. Insect Morphol. Embryol. 10: 93-108.

BILLEN J. 2009: Occurrence and structural organization of the exocrine glands in the legs of ants. - Arthr. Struct. Dev. 38: $2-15$.

Bousn G.M. \& BAERWALDR J. 1967: Courtship behaviour and evidence for a sex pheromone in the apple maggot parasite Opius alloeus (Hymenoptera: Braconidae) - Ann. Entomol. Soc. Am. 60: $865-866$.

BRown P.E. \& ANDERSon M. 1998: Morphology and ultrastructure of sense organs on the ovipositor of Trybliographa rapae, a parasitoid of the cabbage root fly. $-J$. Insect Physiol. 44: $1017-1025$.

Cole L.R. 1970: Observations on the finding of mates by male Phaeogenes invisor and Apanteles medicaginis (Hymenoptera: Ichneumonidae). - Anim. Behav. 18: 184-189.

Copland M.J.W. \& King P.E. 1972: The structure of the female reproductive system in the Chalcididae (Hym.). - Entomol. Mon. Mag. 107: 230-239.

Cormier D., Royer L., Vigneault C., Panneton B. \& Boivin G. 1998: Effect of female age on daily cycle of sexual pheromone emission in gregarious egg parasitoid Anaphes listronoti. $-J$. Chem. Ecol. 24: 1595-1610.

Dallai R., ZizZari Z.V. \& Fanciulli P.P. 2008: Fine structure of the spermatheca and of the accessory glands in Orchesella villosa (Collembola, Hexapoda). - J. Morphol. 269: 464-478.

Field S.A. \& Austin A.D. 1994: Anatomy and mechanics of the telescopic ovipositor system of Scelio Latreille (Hymenoptera: Scelionidae) and related genera. - Int. J. Insect Morphol. Embryol. 23: 135-158.

Gardner S.M., Ward S.A. \& Dixon A.F.G. 1984: Limitation of superparasitism by Aphidius rhopalosiphi: a consequence of aphid defensive behaviour. - Ecol. Entomol. 9: 149-155.

Hofsvang T. 1990: Discrimination between unparasitized and parasitized hosts in hymenopterous parasitoids. - Acta Entomol. Bohemoslov. 87: 161-175.

Höller C., Williams H.J. \& Vinson S.B. 1991: Evidence for a two-component external marking pheromone system in an aphid hyperparasitoid. - J. Chem. Ecol. 17: 1021-1035.

Höller C., Bargen H., Vinson S.B. \& Braune H.J. 1993: Sources of the marking pheromones used for host discrimination in the hyperparasitoid Dendrocerus carpenteri. - J. Physiol. Entomol. 39: 649-656.

Hosken D.J. \& WARD P.I. 1999: Female accessory reproductive gland activity in the yellow dung fly Scathophaga stercoraria (L.). - J. Insect Physiol. 45: 809-814.

King P.E. \& Copland M.J.W. 1969: The structure of the female reproductive system in the Mymaridae (Chalcidoidea: Hymenoptera). - J. Nat. Hist. 3: 349-365.

KRISTENSEN N.P. 1991: Phylogeny of extant hexapods. In Naumann I.D. (ed.): The Insects of Australia, 2nd ed. Melbourne University Press, Carlton, pp. 126-140.

Larocca A., Fanti P., Romano V.A., Marsicovetere E., Isidoro N., Romani R., Ruschioni S., Pennacchio F. \& Battaglia D. 2007: Functional bases of host acceptance behaviour in the aphid parasitoid Aphidius ervi. — Physiol. Entomol. 32: 305312.

LeVinson A. \& LeVInson H. 1995: Reflections on structure and function of pheromone glands in storage insect species. - Anz. Schädlingskd. Pflanzenschutz Umweltschutz 68: 99-118. 
Marris G.C., Hubbard S.F. \& Scrimgeour C. 1996: The perception of genetic similarity by the solitary parthenogenetic parasitoid Venturia canescens, and its effects on the occurrence of superparasitism. - Entomol. Exp. Appl. 78: 167-174.

OBARA M. \& KitAno H. 1974: Studies on the courtship behavior of Apanteles glomeratus L. 1. Experimental studies on releaser of wing-vibrating behavior in the male. - Kontyu 42: 208-214.

Oeser R. 1961: Vergleichend-Morphologische Untersuchungen über den Ovipositor der Hymenopteren. - Mitt. Zool. Mus. Berl. 37: 3-119.

Percy J.E. \& Weatherston J. 1971: Studies of physiologically active arthropod secretions: ix. Morphology and histology of the pheromone-producing glands of some female Lepidoptera. - Can. Entomol. 103: 1733-1739.

QUENNEDEY A. 1998: Insect epidermal gland cells: ultrastructure and morphogenesis. In Harrison F.W. \& Locke M. (eds): Microscopic Anatomy of Invertebrates, Insects, Vol. 11A. WileyLis, London, pp. 177-207.

Quicke D.L.J. 1997: Parasitic Wasps. Chapman \& Hall, London, $470 \mathrm{pp}$.

Quicke D.L.J., FitTon M.G. \& HarRis J. 1995: Ovipositor steering mechanisms in braconid wasps. - J. Hymenopt. Res. 4: $110-120$.

Quicke D.L.J., LeRalec A. \& Vilhelmsen L. 1999: Ovipositor structure and function in the parasitic Hymenoptera with an exploration of new hypotheses. - Atti Accad. Naz. Ital. Entomol. Rendiconti 47: 197-239.

RabB R.L. \& BRAdLEy J.R. 1970: Marking host eggs by Telenomus sphingis. - Ann. Entomol. Soc. Am. 63: 1053-1056.

Raina A.K., Wergin W.P., Murphy C.A. \& Erbe E.F. 2000: Structural organization of the sex pheromone gland in Helicoverpa $z e a$ in relation to pheromone production and release. - Arthr. Struct. Dev. 29: 343-353.

RichARDS O.W. 1977: Hymenoptera. Introduction and keys to families. In: Handbooks for Identification of British Insects 6. Royal Entomological Society, London, pp. 1-100.

Riolo P., Ruschioni S., Minuz R.L., Romani R. \& Isidoro N. 2014: Female sex pheromone gland of the boxwood leafminer, Monarthropalpus buxi (Diptera: Cecidomyiidae): morphological and behavioural evidence. - Eur. J. Entomol. 111: 75-81.

RoitBerg B.D. \& MANGel M. 1988: On the evolutionary ecology of marking pheromones. - Evol. Ecol. 2: 289-315.

RoItBerg B.D. \& Prokopy R.J. 1987: Insects that mark host plants. An ecological, evolutionary perspective on host-marking chemicals. - Bioscience 37: 400-406.

Rosi M.C., Isidoro N., Colazza S. \& Bin F. 2001: Source of the host marking pheromone in the egg parasitoid Trissolcus basalis (Hymenoptera: Scelionidae). — J. Insect Physiol. 47: 989-995.

Ruschioni S., Riolo P., Isidoro N., Romani R., Petrucco-Toffolo E., Zovi D. \& Batтisti A. 2015a: Contrasting patterns of host adaptation in two egg parasitoids of the pine processionary moth (Lepidoptera: Thaumetopoeidae). - Environ. Entomol. 44: 480-487.

Ruschioni S., van Loon J.J., Smid H.M. \& van Lenteren J.C. 2015b: Insects can count: Sensory basis of host discrimination in parasitoid wasps revealed. - PLOS ONE 10(10): e138045, $11 \mathrm{pp}$.

SALT G. 1937: Experimental studies in insect parasitism. V. The sense used by Trichogramma to distinguish between parasitized and unparasitized hosts. - Proc. R. Soc. Lond. (B) 122: $57-75$.

SCUDDER G.G.E. 1961a: The functional morphology and interpretation of the insect ovipositor. - Can. Entomol. 93: 267-272.
SCUDDER G.G.E. 1961b: The comparative morphology of the insect ovipositor. - Trans. R. Entomol. Soc. Lond. 113: 25-40.

ScUDDER G.G.E. 1964: Further problems in the interpretation and homology of the insect ovipositor. - Can. Entomol. 96: 405-417.

SCUDDER G.G.E. 1971: Comparative morphology of insect genitalia. - Annu. Rev. Entomol. 16: 379-406.

Sмiтн E.L. 1968: Evolutionary Morphology of Insect Genitalia as Exemplified by the Sawfly Euura (Hymenoptera: Tenthredinidae). University of California, Davis, $330 \mathrm{pp}$.

SмIтH E.L. 1969: Evolutionary morphology of external insect genitalia. 1. Origin and relationships to other appendages. Ann. Entomol. Soc. Am. 62: 1051-1079.

Sмiтн E.L. 1970: Evolutionary morphology of the external insect genitalia. 2. Hymenoptera. - Ann. Entomol. Soc. Am. 63: $1-27$.

SNODGRASS R.E. 1933: Morphology of the insect abdomen. Part II. The genital ducts and the ovipositor. - Smithson. Misc. Collect. 89(8): 1-148.

SNODGRAss R.E. 1935: Principles of Insect Morphology. McGrawHill, New York, 667 pp.

Sturm R. \& Pohlhammer K. 2000: Morphology and development of the female accessory sex glands in the cricket Teleogryllus commodus (Saltatoria: Ensifera: Gryllidae). - Invertebr. Reprod. Dev. 38: 13-21.

TAGAWA J. 1977: Localization and histology of the female sexpheromone-producing gland in the parasitic wasp, Apanteles glomeratus. - J. Insect Physiol. 23: 49-56.

TAGaWA J. 1983: Female sex pheromone glands in the parasitic wasps, genus Apanteles. - Appl. Entomol. Zool. 18: 416-427.

VAN AlPHEN J.J. \& VisSeR M.E. 1990: Superparasitism as an adaptive strategy for insect parasitoids. - Annu. Rev. Entomol. 35: 59-79.

VAN LENTEREN J.C. 1976: The development of host discrimination and the prevention of superparasitism in the parasite Pseudeucoila bochei Weld (Hym: Cynipidae). — Neth. J. Zool. 26: $1-83$.

VAN LENTEREN J.C. 1981: Host discrimination by parasitoids. In Nordlund D.A., Jones R.L. \& Lewis W.J. (eds): Semiochemicals. Their Role in Pest Control. Wiley, New York, pp. 153173.

van Lenteren J.C., Isidoro N. \& Bin F. 1998: Functional anatomy of the ovipositor clip in the parasitoid Leptopilina heterotoma (Thompson) (Hymenoptera: Eucoilidae), a structure to grip escaping host larvae. - Int. J. Insect Morphol. Embryol. 27: 263-268.

VILHeLMSEN L. 2000: The ovipositor apparatus of basal Hymenoptera (Insecta): phylogenetic implications and functional morphology. - Zool. Scr. 29: 319-345.

Vilhelmsen L. 2001: Phylogeny and classification of the extant basal lineages of the Hymenoptera (Insecta). - Zool. J. Linn. Soc. Lond. 131: 393-442.

VILHELMSEN L. 2003: Flexible ovipositor sheaths in parasitoid Hymenoptera (Insecta). - Arthr. Struct. Dev. 32: 277-287.

VINSON S.B. 1972: Courtship behavior and evidence for a sex pheromone in the parasitoid Campoletis sonorensis (Hymenoptera: Ichneumonidae). — Environ. Entomol. 1: 409-414.

VINSON S.B. 1978: Courtship behavior and source of a sexual pheromone from Cardiochiles nigriceps. - Ann. Entomol. Soc. Am. 71: 832-837.

VINSON S.B. 1985: The behavior of parasitoids. In Kerkut G.A. \& Gilbert L.I. (eds): Comprensive Insect Physiology Biochemistry and Pharmacology, Vol. 9. Pergamon, Oxford, pp. 417-469.

VINSON S.B. 1998: The general host selection behavior of parasitoid Hymenoptera and a comparison of initial strategies uti- 
lized by larvaphagous and oophagous species. - Biol. Contr. 11: 79-96.

VÖLKL W. \& MACKaUER M. 2000: Oviposition behaviour of aphidiine wasps (Hymenoptera: Braconidae, Aphidiinae): morphological adaptations and evolutionary trends. - Can. Entomol. 132: 197-212.
Wang S. \& HuAng Y. 1991: Marking pheromone and its role in host discrimination in Telenomus dendrolimus. - Colloq. INRA France 56: 97-100.

Whiting P.W. 1932: Reproductive reactions of sex mosaics of a parasitic wasp, Habrobracon juglandis. - J. Comp. Psychol. 14: $345-363$.

Received November 15, 2017; revised and accepted April 12, 2018 Published online June 19, 2018 